\title{
Editorial: Parting Words and Opening Thoughts
}

Ten years ago, Mark Rosenberg marked the end of his term as Editor-in-Chief of the Canadian Journal on Aging / La Revue canadienne $d u$ vieillissement with an editorial titled "I never knew gerontology could be so interesting..." (Rosenberg, 2010). As I complete my 5-year term as Editor-in-Chief, I find myself in agreement with Dr. Rosenberg. Although I have been involved in research in gerontology for what I am surprised to realize has now been four decades, one of the great pleasures of my editorial role has been my heightened awareness and appreciation of the breadth and depth of excellent gerontological research submitted to the Canadian Journal on Aging / La Revue canadienne du vieillissement. I am grateful to the many Canadian and international scholars who have supported the Canadian Journal on Aging / La Revue canadienne du vieillissement with their submissions on all aspects of aging, from a wide range of disciplinary perspectives. One of the strengths of the Canadian Journal on Aging / La Revue canadienne $d u$ vieillissement is its capacity to reflect the diversity of gerontological research and the diversity of experiences of aging.

It has been an honour to serve the Canadian Journal on Aging / La Revue canadienne du vieillissement and the Canadian Association on Gerontology, in this role. I am grateful for the consistent support I have received from the Canadian Association on Gerontology board, a strong Editorial Board, excellent staff, and the team at Cambridge University Press. With this support, I believe the Canadian Journal on Aging / La Revue canadienne $d u$ vieillissement has made good progress over the past 5 years, continuing the strong record of scholarship and stewardship provided by my predecessors. There is still much room to strengthen the Canadian Journal on Aging / La Revue canadienne du vieillissement, and I am grateful that Dr. Pierrette Gaudreau has agreed to take on this challenge. I offer her and the Editorial Board my best wishes.

I feel very privileged to succeed to Dr. Paul Stolee as Editor-in-Chief of the Canadian Journal on Aging / La Revue canadienne du vieillissement. With the contribution of the present highly distinguished intersectorial Editorial board, I can assure the readership that we will continue in the coming years to deploy constant efforts to publish the highest quality research in the Canadian Journal on Aging / La Revue canadienne du vieillissement.

I strongly believe that Canadian research in the field of aging needs to have a strong voice and an increasing impact at the Canadian and international level. Consequently, the Editorial Board will identify actions to raise the interest in submitting manuscripts in the field of psychology, social sciences, social policy and practice, and health sciences and biological sciences, with a special emphasis on geroscience, which is at the intersection of basic aging biology, chronic diseases, and health maintenance (National Institute on Aging [NIA] National Institutes of Health [NIH]).

Because the present COVID-19 pandemic is very challenging for older adults, we found it important to include two editorials providing food for thought on several research questions related to this health crisis in the present issue. Moreover, as numerous studies are presently evaluating how older adults cope with this threatening situation, we will offer to researchers an opportunity to disseminate these unique results in a 2021 special issue of Journal on Aging / La Revue canadienne $d u$ vieillissement, on the impacts of COVID-19 on the elderly population.

Finally, I sincerely thank Dr. Stolee and his team, and personnel from Cambridge University Press, for their essential support in the present transition period.

Je me sens très privilégiée de succéder au Dr Paul Stolee à titre de rédactrice en chef de la Revue canadienne $d u$ vieillissement. Avec la contribution de l'actuel comité de rédaction intersectoriel très distingué, je peux assurer au lectorat que nous continuerons dans les années à venir à déployer des efforts constants pour publier des recherches de la plus haute qualité dans la Revue canadienne $d u$ vieillissement.

Je crois fermement que la recherche canadienne dans le domaine du vieillissement doit avoir une voix forte et un impact croissant au niveau canadien et international. Par conséquent, le comité de rédaction identifiera des actions pour susciter l'intérêt de soumettre des manuscrits dans le domaine de la psychologie, des sciences sociales, des politiques et pratiques sociales, ainsi que des sciences de la santé et de la biologie, avec une emphase particulière en géroscience, qui se situe à l'intersection de la recherche en biologie du vieillissement, en maladies chroniques et en maintien de la santé (Institut national sur le vieillissement [INV], Instituts nationaux de la santé [INS]).

Comme la pandémie actuelle de COVID-19 est très difficile pour les personnes âgées, nous avons jugé important d'inclure dans le présent numéro, deux 
éditoriaux donnant matière à réflexion sur plusieurs questions de recherche liées à cette crise sanitaire. De plus, comme de nombreuses études évaluent présentement la façon dont les personnes âgées font face à cette situation menaçante, nous offrirons aux chercheurs l'occasion de diffuser ces résultats uniques dans un numéro spécial 2021 de Revue canadienne du vieillissement, portant sur les impacts du COVID-19 dans la population âgée.

Finalement, je remercie sincèrement le Dr Stolee et son équipe, ainsi que le personnel de Cambridge University Press, de leur soutien essentiel dans la période de transition actuelle.

\section{References}

Rosenberg, M. (2010). Editorial: I Never Knew Gerontology Could Be So Interesting .... Canadian Journal on Aging / La Revue Canadienne Du Vieillissement, 29(4), 473-473. doi:10. 1017/S0714980810000656. https://www.nia.nih.gov/ research/dab/geroscience-intersection-basic-aging-

biology-chronic-disease-and-health

\section{Paul Stolee and Pierrette Gaudreau}

